Portland State University

PDXScholar

2014

\title{
Trace Metal Analysis of Drinking Water at Portland State University
}

\author{
Emma Claire Prichard \\ Portland State University
}

Follow this and additional works at: https://pdxscholar.library.pdx.edu/honorstheses

\section{Let us know how access to this document benefits you.}

\section{Recommended Citation}

Prichard, Emma Claire, "Trace Metal Analysis of Drinking Water at Portland State University" (2014). University Honors Theses. Paper 173.

https://doi.org/10.15760/honors.125

This Thesis is brought to you for free and open access. It has been accepted for inclusion in University Honors Theses by an authorized administrator of PDXScholar. Please contact us if we can make this document more accessible: pdxscholar@pdx.edu. 


\section{Trace metal analysis of drinking water at Portland State University}

By

Emma Claire Prichard

A thesis submitted in partial fulfillment of the requirements for the degree of

Bachelor of Science

in

Environmental Sciences

and

Honors

Thesis Advisor:

Olyssa Starry

Portland State University, 2014 


\begin{abstract}
Clean drinking water is essential for human and environmental health, but pollution of drinking water sources due to lack of resources or investment allows poor drinking water quality to be pervasive even in developed areas. Portland State University, located in Portland, OR, U.S.A., had reports of poor drinking water quality in a major academic building (Cramer Hall). In order to investigate, a trace metals analysis of drinking water was conducted using EPA Method 200.7 Section 8.2: Dissolved Metals, via Inductively Coupled Plasma - Optical Emission Spectrometry (ICP-OES). Concentrations of 10 different metals were determined in 22 building areas. Results show the following metals present in one or more areas at levels above United States E.P.A. Maximum Contaminant Level Goals: Iron, Manganese, and Lead. Future research is being conducted to guide potential policy changes at the university.
\end{abstract}

\title{
Acknowledgments
}

Many thanks to Dr. Olyssa Starry for her dedication to this project, and Dr. Ben Perkins for his gracious assistance preforming the ICP-OES analysis and for all of his help. Additionally, thanks to Nora Quiros, and Dr. Elise Granek for all their logistical support and last-minute help. 


\section{INTRODUCTION}

\section{Brief Overview}

This thesis conducts a trace metals analysis of contaminated drinking water in Portland State University's (PSU) Cramer Hall $(\mathrm{CH})$ to determine:

1. Is Cramer Hall drinking water contaminated?

2. Can sources of contamination be identified?

Portland State University is located in Portland, Oregon and is served by the municipal water system. Faculty and Students complained about poor water quality in this building, which lead to the present analysis. Built in 1955, CH is one of the oldest buildings on PSU's campus and therefore has older plumbing than most. Because plumbing from 1950-1960 is most likely to be galvanized or iron (Ryder 1980), I hypothesized trace metals were the most likely source of contamination. Environmental Protection Agency standards provide the legal framework for required levels of metals in drinking water (EPA 816-R-99-007). National Primary Drinking Water Regulations are mandatory for all states and include the metals Antimony, Arsenic, Barium, Beryllium, Cadmium, Chromium, Copper, Cyanide, Lead, Mercury, Selenium, and Thallium. Secondary Drinking Water Regulations are not mandatory for all states_although some enforce them — and include the metals Aluminum, Iron, Manganese, Silver, and Zinc. I present the hypothesis that water from $\mathrm{CH}$ will meet all primary drinking water regulations, but not meet all secondary drinking water regulations. Additionally, I hypothesized that any contamination of water will come from plumbing belonging to PSU and not from plumbing belonging to the City of Portland.

\section{Global and Historical Significance}

The United Nations "recognizes the right to safe and clean drinking water and sanitation as a human right that is essential for the full enjoyment of life and all human rights" 
(A/RES/64/292 UN General Assembly 28 July 2010). Clean drinking water is essential for human and environmental health, but pollution of drinking water sources, inadequate delivery systems, and a historical lag in government regulation has allowed poor quality drinking water to be pervasive throughout history.

Municipal drinking water systems began as early as the construction of the Roman aqueducts and the traditional water harvesting systems used in India (Agarwhal 1997). The presence of these early systems demonstrates the historically pressing need for expansive access to clean drinking water, especially in growing municipalities. In the early American west drinking water was critical to any development or expansion of early townships (Short 2011). The first municipal water system was in the United States was installed in Philadelphia in 1799 (Derouin and Nelson 2007). Growth over the next 200 years resulted in over 62,000 delivery systems in 1980 (EPA 816-R-99-007 December 1999). Portland, Oregon's first delivery system was built in 1856 (Short 2011). Only a small network on drilled fir logs were laid underneath the streets, and the early Pioneer Water Works began to develop in to the Portland Water Bureau that provides water to over 900,000 Oregonians in 2015 (Short 2011).

\section{Drinking Water Quality and Sustainability}

Persistent trouble with pollution in water sources and delivery systems motivated the need for drinking water regulation. In 1854 London, numerous Cholera outbreaks were sourced from severely polluted drinking water (Paneth et al. 1998, Short 2011). From 1830-1930, France converted from private, local drinking water sources to a universal access system (Bocquet et al. 2008). In 1890s Philadelphia, water was drawn downstream from sewage and industrial waste disposal, resulting in the occurrence of typhoid fever and other waterborne infections (Holst 2007). In 1880s Portland, waste from upstream settlements polluted the city's water supply at the 
time, the Willamette River (Short 2011). Contaminant composition changed after the industrial and agricultural revolution; inorganic compounds such as metals, nitrates, and asbestos and organic compounds such as solvents or pesticides entered waterways through farming and manufacturing discharge (EPA 816-R-99-007 December 1999), rather than the sewage that solely plagued waterways prior to the advent of synthetic chemical manufacturing.

Federal regulation of drinking water in the United States began in 1914 (Pontius, "History of Safe Drinking Water"), after the development of Germ theory by Louis Pasteur in the late 1880 s. The first regulations only applied to interstate carriers of drinking water. Additional regulations were created from 1925-1962. The Clean Water Act of 1972 protects public drinking water sources indirectly by regulating pollutant discharges into waterways and regulating quality standards for surface waters (33 U.S.C. 1251 et seq.). The Safe Drinking Water Act (SDWA) of 1974, 1986, and 1996 provide the somewhat comprehensive drinking water legislation that exists today (EPA 816-R-99-007 December 1999). The SDWA sets Maximum Contaminant Levels (MCLs) for contaminants in response to the frequency of their occurrence in national water supplies and the risk that they pose to human health (EPA 816-F-04-030). MCLs are supplemented by Maximum Contaminant Level Goals (MCLGs) which set a stricter standard for a wider suite of contaminants (EPA 816-F-04-030). The World Health Organization (WHO) and the European Union (EU) publish similar regulations. For a side-by-side comparison of world drinking water regulations, see Appendix B.

Environmental inputs of pollutants are commonly studied, but not entirely inclusive. In addition to pollutants that come from outside the delivery system, plumbing corrosion may cause contamination at the tap that was not present at the source waters (Ryder 1980, Sarin et al. 2004). Particulate due to corrosion or oxidation may produce suspensions of iron, manganese, and zinc 
that give drinking water a red, brown, or yellow color. The corrosion can damage piping, create scales, consume important oxidants and disinfectants in the water, and support biofilm growth (Sarin et al. 2004). Federal regulations do not regulate water quality once the municipal water supply has entered the building of interest. Household, industrial, and commercial plumbing upkeep is the responsibility of the building owner (SDWA 2002).

\section{Portland State University}

Portland State University's water system begins at the municipal system. Each building has it's own connection to a city main (portlandmaps.com). Cramer Hall, built in 1955, is one of the oldest buildings on Portland State University's campus; therefore the plumbing is a different age and composition than in most campus buildings.

Take Back the Tap is a campaign run by students at PSU. The campaign began in 2009 as an effort to ban single-use plastic bottles at the University. The author of this study coordinated the Take Back the Tap campaign from 2012-2015. In 2014 the campaign aimed to halt the departmental use of water coolers, bottled water, and non-tap drinking water services. Informal reports indicated that drinking water quality in Cramer Hall, a primary academic building located in the middle of PSU's campus, was subpar.

Faculty with offices in Cramer Hall answered a survey about drinking water quality in their offices. When asked why water coolers and alternative drinking water services are used they responded, "old habits die hard...the water comes out of the tap a brown color....ability to cool or heat water easily...instant hot water is useful for tea....automatic hot water...concerns about tap water quality." They also posed questions about whether filers in university hydration 
stations are changed, and indicted concerns about the quality of plumbing in older campus buildings. These results indicate drivers of water cooler use at PSU.

A target of the Take Back the Tap campaign is halting departmental use of water coolers, bottled water, and non-tap drinking water services. Common economic, environmental, and social justice concerns about bottled water use drive the motivation behind the student campaign and initiated the idea for this study. The purpose of this study is to determine the quality of the water in Cramer Hall. Departments will be informed if their tap water meets federal regulations, and any epidemiologically harmful preset and if they meet or exceed federal drinking water standards. If samples do not meet federal regulations, repair steps will be initiated so that clean, drinkable water can be accessible to every user of the university. Additionally, this will allow departments, students, and the university to save money by canceling non-tap drinking water service purchases. The university currently spends over $\$ 30,000 /$ year on these services, including the bottled water purchased by departments.

I hypothesize that water in Portland State University's Cramer Hall will meet primary drinking water regulation or regulated trace metals, but will not meet secondary drinking water regulations. A null hypothesis states water will meet all drinking water regulations. Additionally, it is further hypothesized that any contamination of water will come from plumbing belonging to Portland State University. The alternative hypothesis states that the source of contamination will not be able to be identified.

\section{METHODS}

Sampling Location 
Cramer Hall has several cold and hot water mains running vertically throughout the building (see Document 201_A1-201_A7, Capital Projects and Construction, 201-CH M-1 to M18 especially M-3, Lawrence Tucker \& Wallman Architects). Each section of piping in the building could have varying levels of contamination due to differences in age and composition of the plumbing. Sampling locations were chosen to determine if contaminant levels varies throughout the building in relation to location. Taking replicate east, west, north, and south bathroom samples on various floors allowed for comparison between the same mains and could show any difference in quality from the basement to the fifth floor. On alternating floors, samples were taken at drinking fountains in each hallway (Floors 1-4). Samples were taken in all departmental sinks. Alternate floor plans in the basement, sub-basement, and $5^{\text {th }}$ floor required varying the sample design. Sampling locations in the basements and $5^{\text {th }}$ floor included bathrooms, lab and departmental sinks, and water fountains. Samples were taken immediately upon turning on the tap after a night of no use. This allows us to determine the highest representative concentration of contaminants present in this drinking water.

Table 1: Sampling locations in Cramer Hall, Portland State University. WC $=$ Water Closet (Bathroom Sink). WF = Water Fountain (Hallway). Room numbers reported for water fountains were the closest visible room number to that location. See Appendix $\mathrm{C}$ for sampling location maps.

\begin{tabular}{|c|c|c|c|c|}
\hline Location Name & Floor & $\mathrm{Rm} \#$ & $\begin{array}{l}\text { Bottle } \\
\#\end{array}$ & $\begin{array}{l}\text { Time } \\
\text { (AM) }\end{array}$ \\
\hline East Womens WC_1 & 1 & $170 \mathrm{~A}$ & 1 & $7: 56$ \\
\hline North Womens & 1 & 105 & 2 & 8:00 \\
\hline West Mens WC_3 & 1 & $195 \mathrm{~B}$ & 3 & 8:06 \\
\hline $\begin{array}{l}\text { Anthropology Dept. } \\
4\end{array}$ & 1 & 141 & 4 & $8: 10$ \\
\hline S Hallway WF_5 & 2 & 280 & 5 & $8: 17$ \\
\hline Economics_6 & 2 & 241 & 6 & $8: 22$ \\
\hline Sociology Dept. _7 & 2 & 217 & 7 & $8: 31$ \\
\hline
\end{tabular}




\begin{tabular}{lrrrr}
\hline NHallWF_8 & 3 & 352 & 8 & $8: 36$ \\
North Womens & 3 & 305 & 9 & $8: 39$ \\
WC_9 & & & & \\
Psychology_10 & 3 & 317 & 10 & $8: 46$ \\
E Womens WC_12 & 3 & 370 & 12 & $8: 50$ \\
Office of the & 3 & 341 & 13 & $8: 56$ \\
Dean_13 & & & & \\
SHallway WF_14 & 4 & 480 & 14 & $9: 03$ \\
WHallway WF_15 & 4 & 453 & 15 & $9: 07$ \\
History_16 & 4 & 441 & 16 & $9: 14$ \\
Geography_17 & 4 & 463 & 17 & $9: 25$ \\
Geography_18 & 4 & 469 & 18 & $9: 25$ \\
5th Floor WF_19 & 5 & 539 & 19 & $9: 34$ \\
Geology_20 & B & 17 & 20 & $9: 40$ \\
SB WF_21 & SB & S5 & 21 & $9: 51$ \\
SB Lab Sink_22 & SB & S13 & 22 & $9: 51$ \\
\hline
\end{tabular}

\section{Sample Preparation}

Sampling methodology was based on U.S. Environmental Protection Agency Methods for Chemical Analysis of Water and Wastes—Metals Atomic Absorption Methods. Sample bottles, and all other relevant laboratory equipment, were washed with detergent, rinsed with tap water, and soaked for 48 hours in $4 \% \mathrm{HCl}$. Upon removal, equipment was rinsed with DI water, shaken, emptied, capped and closed.

\section{Sample Collection}

During collection, a 200ml bottle was placed under the tap and then the tap was turned on so that the first use of the day was collected. A separate $500 \mathrm{~mL}$ bottle was filled after the $200 \mathrm{~mL}$ bottle and a probe was used to collect temperature, $\mathrm{pH}$, and conductivity for each sample.

\section{Sample Preservation}

Samples were filtered through a $0.45 \mu \mathrm{m}$ glass fiber filter using a vacuum filter manifold. Samples were then returned to the bottles they were initially collected in. The filter manifold and 
other glassware was rinsed twice with DI water between each filtering. After filtration, 15 drops of trace metal analysis grade $\mathrm{HNO}_{3}$ was added to all samples to reduce $\mathrm{pH}$ to less than 2. Bottles were capped and inverted 5 times. An Agilent 720 Axial Inductively Coupled Plasma Optical Emission Spectrometer was used to analyze samples. Dr. Ben Perkins guided the procedure. For laboratory protocols see Appendix A.

\section{Analytes}

Emission spectroscopy heats elements by a flame so that they emit energy in the form of light. Each element produces a different, discontinuous spectrum of light, when examined with a spectroscope. Each element has its own line spectrum that can use used to determine the composition of a mixture of elements. Inductively coupled plasma is a type of plasma where electric currents produced by electromagnetic induction (time-varying magnetic fields). Inductively coupled plasma atomic emission spectroscopy (ICP-OES) in an analytical technique that provides qualitative and quantitative information about the concentration of trace metals in solution. It uses the inductively coupled plasma to excite atoms so that they emit their characteristic line spectrum, which can then be measured by the optical spectrometer. The ICP torch contains 3 concentric quartz glass tubes surrounded by a radio frequency (RF) generator. Argon gas is fired through the torch, which is creating an intense electromagnetic field. The argon gas is then ignited briefly with a Tesla unit, starting ionization. The ionized gas rotates towards the magnetic field and collides creating a high temperature (7000K) plasma.

A peristaltic pump delivers the sample into the machine where it is misted into the plasma flame. The sample is broken down into charged ions upon contact, and then repeatedly reform and recombine, giving off their characteristic line spectrum. The light is directed into separate optical changers where the light is separated into different wavelengths and the intensity 
of light is measured by a photomultiplier tube. The intensity of each elemental line spectra can then be compared against known measured concentrations of the element (standards) to determine the concentration of the element in the sample. The ICP-OES software also attempts to correct for interferences caused by the presence of different elements in a singular sample mixture.

I tested for the most common weight of an element, and for the metals most likely to be regulated or detected in this water system: Aluminum (236.705), Arsenic (193.696), Cadmium (214.439), Chromium (267.716), Copper (327.395), Iron (238.204 and 258.588), Manganese (260.568), Nickel (231.604), Lead (220.353), and Zinc (206.200).

\section{RESULTS}

Elemental concentrations are detected in intensity and converted to concentration (parts per billion) via a linear relationship. Correlation coefficients reflecting the accuracy of standard curves used to predict sample values can be found in Appendix A. The instrument detection limit, the method reporting limit, and the lowest standard included for each analyte is listed in Table 2. Results of this study show concentrations of dissolved trace metals in Cramer Hall drinking water (Table 3).

Table 2: IDL = Instrument Detection Limit found by 3 x stdev of 7 near-blank standards; MDL = "Method Reporting Limit" found by 10 x stdev of 7 near-blank standards. Includes IDL, MRL, and Lowest Standard used for each element.

\begin{tabular}{|c|c|c|c|c|c|c|c|c|c|c|}
\hline $\begin{array}{l}\text { Element } \\
\text { Wavelengt } \\
\mathrm{h}\end{array}$ & $\begin{array}{l}\mathrm{Al} \\
237.3 \\
12\end{array}$ & $\begin{array}{l}\text { As } \\
193.6 \\
96\end{array}$ & $\begin{array}{l}\mathrm{Cd} \\
214.4 \\
39\end{array}$ & $\begin{array}{l}\mathrm{Cr} \\
267.7 \\
16\end{array}$ & $\begin{array}{l}\mathrm{Cu} \\
327.3 \\
95\end{array}$ & $\begin{array}{l}\mathrm{Fe} \\
258.5 \\
88\end{array}$ & $\begin{array}{l}\text { Mn } \\
260.5 \\
68\end{array}$ & $\begin{array}{l}\mathrm{Ni} \\
231.6 \\
04\end{array}$ & $\begin{array}{l}\mathrm{Pb} \\
220.3 \\
53\end{array}$ & $\begin{array}{l}\mathrm{Zn} \\
202.5 \\
48\end{array}$ \\
\hline IDL & 1.27 & 1.43 & 0.16 & 0.31 & 0.17 & 1.38 & 0.20 & 0.47 & 0.90 & 0.94 \\
\hline MRL & 4.22 & 4.76 & 0.55 & 1.03 & 0.58 & 4.58 & 0.68 & 1.55 & 2.98 & 3.14 \\
\hline $\begin{array}{l}\text { Lowest } \\
\text { Standard }\end{array}$ & 4.0 & 4.0 & 4.0 & 4.0 & 4.0 & 10.0 & 4.0 & 4.0 & 4.0 & 10.0 \\
\hline
\end{tabular}


See Table 3 for concentrations of each sample, in addition to United States

Environmental Protection Agency Maximum Contaminant Level Goals (MCLGs) and Secondary Maximum Contaminant Level Goals (SMCLGs) in mg/L and ppb. Method Reporting Limits (MRLs) and reported for quick reference. $36.4 \%$ of samples exceeded or within $10 \%$ of the SMCLG for iron. $13.6 \%$ of samples exceeded the SMCLG for manganese. $27.3 \%$ exceeded 0 ppb lead, the EPA Primary MCLG. The EPA action level for lead is $15 \mathrm{ppb}$; one sample (SBLabSink_22) contained 13.63 ppb lead or within 10\% of the action level. $45.5 \%$ of samples exceeded or were within $10 \%$ of the MCLG or SMCLG for at least one of the analytes measured.

The highest value reported for Aluminum was $11.96 \mathrm{ppb}$. No arsenic was detected in any sample. The highest level of Cadmium detected was $0.77 \mathrm{ppb}$. No Chromium was detected in any sample. The highest level of Copper detected was $454.7 \mathrm{ppb}$, the lowest level of Copper detected was $1.96 \mathrm{ppb}$. The highest level of Iron detected was $599.44 \mathrm{ppb}$, the lowest level was $7.82 \mathrm{ppb}$. The highest level of Manganese detected was $94.09 \mathrm{ppb}$, the lowest level was $5.22 \mathrm{ppb}$. The highest level of Nickel detected was $16.13 \mathrm{ppb}$. The highest level of lead detected was 13.63 ppb. The highest level of zinc detected was $1905.05 \mathrm{ppb}$, the lowest level of Zinc detected was $98.89 \mathrm{ppb}$.

Figure 1: Concentrations of Manganese in ppb including error bars showing +/- the Standard Deviation. The Secondary Maximum Contaminant Level for Manganese is $50.06 \mathrm{ppb}$. Sample ID correlated with Table 1.

Figure 2: Concentrations of Lead in ppb. EPA Action Level for Lead is $15 \mathrm{ppb}$. All samples taken but not reported here had levels of lead below the Method Detection Limit. Figure 3: Concentrations of Iron (238.204) in ppb in all sample locations. The Secondary Maximum Contaminant Level for Iron is $300.3 \mathrm{ppb}$.

Figure 4: Concentrations of Copper in ppb in all sample locations. 


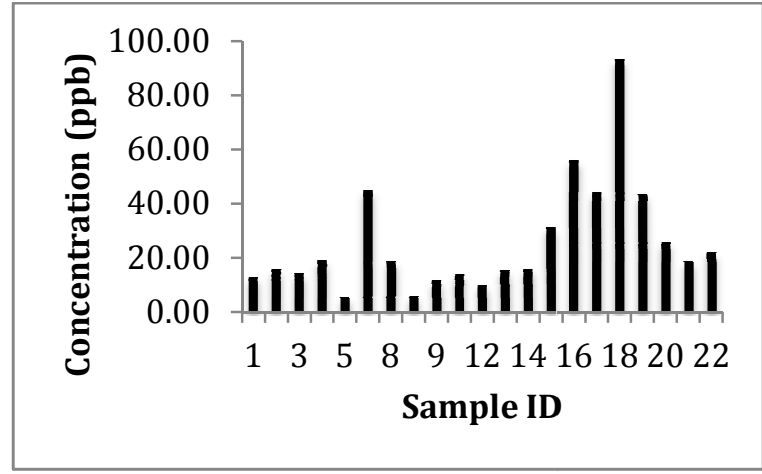

Figure 1

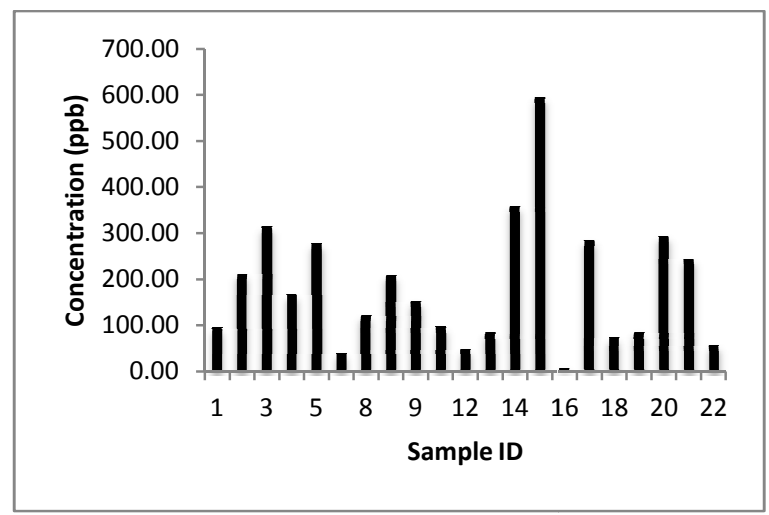

Figure 3

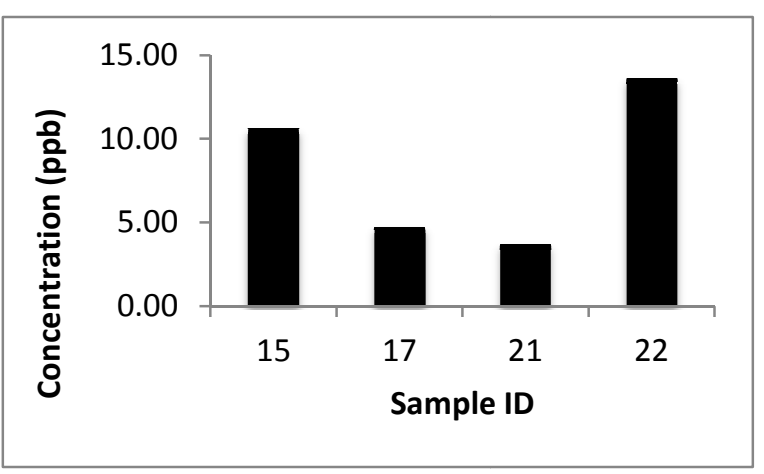

Figure 2

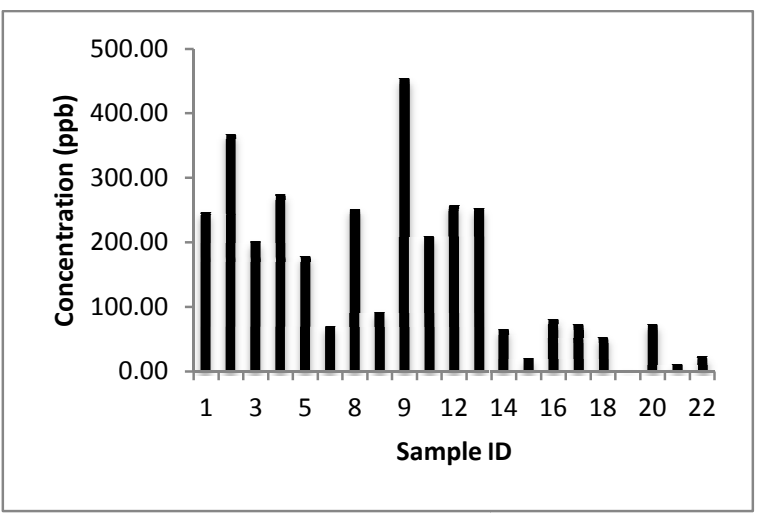

Figure 4

Manganese, iron, copper and zinc had the highest mean concentrations of analytes. Three iron samples (floors 1 and 4) and two Manganese samples (floor 4) exceeded EPA Secondary Drinking Water Regulations. Three additional iron samples were within 10\% of EPA SDWR. All lead samples above the MRL are highlighted because they exceeded the MCL of $0 \mathrm{ppb}$, but are not high enough to warrant treatment at $15 \mathrm{ppb}$. 
Table 3: Summary table showing samples that exceeded EPA standards. Cells highlighted in red show samples that exceeded the Secondary Maximum Contaminant Level. Cells highlighted in yellow show samples within $10 \%$ of the Secondary Maximum Contaminant Level. Lead is regulated by requiring treatment at $15 \mathrm{ppb}$. Samples reported and highlighted in yellow are above 0 ppb but below 15 ppb. To see sample locations review maps in Appendix.

\begin{tabular}{|c|c|c|c|c|c|c|}
\hline Floor & $\begin{array}{l}\text { Sample } \\
\text { ID }\end{array}$ & Sample Label & Fe 238.204 & Fe 258.588 & $\begin{array}{l}\text { Mn } \\
260.568\end{array}$ & $\begin{array}{l}\mathrm{Pb} \\
220.353\end{array}$ \\
\hline \multicolumn{3}{|c|}{ EPA Secondary Standard } & $300.3 \mathrm{ppb}$ & $300.3 \mathrm{ppb}$ & $50.06 \mathrm{ppb}$ & $15 \mathrm{ppb}$ \\
\hline 1 & 1 & East Bathroom & 96.10 & 95.42 & 12.62 & \\
\hline 1 & 2 & North Bathroom & 212.30 & 209.39 & 15.43 & \\
\hline 1 & 3 & West Bathroom & 314.39 & 309.81 & 14.05 & \\
\hline 1 & 4 & Anthropology & 167.60 & 165.97 & 18.98 & \\
\hline 2 & 5 & South Water Fountain & 278.14 & 272.40 & 5.22 & \\
\hline 2 & 6 & Economics & 40.84 & 41.63 & 44.71 & \\
\hline 3 & 8 & North Water Fountain & 121.89 & 120.90 & 18.49 & \\
\hline 2 & 7 & Sociology & 208.53 & 204.99 & 5.69 & \\
\hline 3 & 9 & North Bathroom & 152.51 & 150.67 & 11.61 & \\
\hline 3 & 10 & Psychology & 97.04 & 95.63 & 13.82 & \\
\hline 3 & 12 & East Bathroom & 48.80 & 48.46 & 9.86 & \\
\hline 3 & 13 & Deans Office & 84.43 & 84.47 & 15.16 & \\
\hline 4 & 14 & Water Fountain & 359.49 & 352.87 & 15.85 & \\
\hline 4 & 15 & West Water Fountain & 595.40 & 583.45 & 31.22 & 10.64 \\
\hline 4 & 16 & History & 7.82 & 8.82 & 55.82 & \\
\hline 4 & 17 & Geography 463 & 285.52 & 282.32 & 43.92 & 4.73 \\
\hline 4 & 18 & Geography 469 & 73.90 & 74.35 & 93.28 & \\
\hline 5 & 19 & Water Fountain & 86.05 & 85.99 & 43.11 & \\
\hline $\mathrm{B}$ & 20 & Geology & 293.45 & 290.26 & 25.58 & \\
\hline SB & 21 & Water Fountain & 244.56 & 239.84 & 18.49 & 3.70 \\
\hline SB & 22 & Lab Sink & 57.08 & 56.38 & 21.77 & 13.63 \\
\hline
\end{tabular}

\section{DISCUSSION}

All samples met Primary Drinking Water Regulations for Aluminum, Arsenic, Cadmium, Chromium, Nickel, and Zinc. Secondary regulations were exceeded in three samples for iron, and three samples for manganese. Some samples had levels of lead within $10 \%$ of the $15 \mathrm{ppb}$ action level. Levels of iron above secondary concentrations cause poor odor, taste and a red to brown color and may point to a high concentration of scale and sediment due to corrosion in the 
water. Levels of manganese above secondary concentrations have similar effects on drinking water but discoloration is often brown or black. Levels of copper above primary regulations cause gastrointestinal distress, and liver/kidney damage over long-term exposure. Levels of lead above 15 ppb causes delays in physical or mental development in children, kidney problems, blood pressure issues, brain damage, or death. Water that has concentrations of iron or manganese above secondary MCLGs may give users that the water is unsafe to drink, decreasing tap water usage and increasing corrosion. Corrosion occurs primarily when water stagnates within a section of pipe (Sarin et al. 2004, Cerrato 2005, Kumpel and Nelson 2014).

Water enters Cramer Hall from under SW Mill St. on the North side of the building, into the sub-basement. Several mains run to each floor and the roof. Plumbing branches off from each of these mains to tap sources throughout the building. The length of piping between the main and the tap (the dead leg) could correlate with the amount of sedimentation in each tap, although this is an area for future research. The plumbing in Cramer Hall is primarily galvanized piping, steel coated with zinc. This piping has a serviceable lifespan between 35 and 100 years (Ryder 1980). Cramer Hall's plumbing is around 62 years old (Personal Communication). The nature of the plumbing suggests the source of the scale and sediment found in the water samples-the pipes are simply old. Lead concentrations suggest that lead soldering may have been used in the lower floors of the building. As piping corrodes, lead soldered joints are exposed and lead corrodes into water supplies. Because of the acute toxicity of lead, this is the highest human health priority discovered by this study.

Oregon regulations do not enforce Federal Secondary Regulations (Oregon 1981), so no action is required when Secondary standards are exceeded. The current water quality decreases usage due to the perception that the water is unhealthy. Decreased usage increases corrosion and 
decreases water quality, further decreasing usage. Without investment into sustainable drinking water infrastructure, quality of plumbing will continue to decline.

This analysis was conducted using a 'dissolved metals' method. All samples were filtered before being tested for trace metals. Because of this, the concentrations of metals present in the water were likely less than what is present including sediment and scale. This poses a concern primarily for the levels of lead detected in samples that were above the method detection limit. If there is some amount of lead in the sediment, several taps could have levels of lead exceeding the EPA action level. In this case, repairs should be made immediately or risk federal responsibility/legal action.

The data is limited temporally and spatially. Future studies could sample from Cramer Hall at varying times of the day, week, and year, to further our understanding of what risk is involved when drinking university water. Samples not taken on the 'first draw' method may show concentrations of trace metals below what I detected in this study. Samples could be taken from Hydration Locations-stand alone water bottle refilling stations that are filtered. These Hydration Locations are used frequently by students, faculty, and staff, and more are being continuously installed around the university. The quality of drinking water (including the concentrations of trace metals and microbials) should be assessed in these stations.

Further research is currently being conducted to verify the results of this study. Samples are being submitted to ALS Labs in Kelso, WA so that my results can be confirmed, and the university can know that any policy changes that they make are due to professionally sound analytics. For results of this future research, contact the author. 


\section{Conflict of Interest}

Because of the authors involvement with the Take Back the Tap campaign, the author recognizes a conflict of interest and notes that care was taken to ensure the least amount of bias possible in the data collection and analysis.

\section{REFERENCES}

Alomary, A., Jordan, C., 2013. Determination of trace metals in drinking water in Irbid CityNorthern Jordan. Environ. Monit. Assess. 185, 1969-1975. doi:10.1007/s10661-012$2680-3$

Anil Agarwal, Sunita Narain. Centre for Science and Environment New Delhi 1997. Dying wisdom: rise, fall and potential of India's traditional water harvesting systems.

Batley, G.E., Gardner, D., 1977. Sampling and Storage of Natural Waters for Trace Metal Analysis. Water Res. 11, 745-756.

Bocquet, D., Chatzis, K., Sander, A., 2008. From free good to commodity: Universalizing the provision of water in Paris (1830-1930). Geoforum 39, 1821-1832. doi:10.1016/j.geoforum.2008.09.007

Cerrato, J.M., 2005. Impact of piping materials on water quality in Teguciagalpa, Honduras. Virginia Polytechnic Institute and State University. Thesis.

Eljarrat, E., 2012. Comprehensive Sampling and Sample Preparation. Reference Module in Chemistry, Molecular Sciences and Chemical Engineering Analytical Techniques for Scientists 1, 31-49. Elsevier. doi:10.1016/B978-0-12-381373-2.00004-1

ENCO Labratories, ENCO Labratories Chembook III.

Federal Water Pollution Control Act, 2002. United States. 
Holst, A., 2007. The Philadelphia Water Department and the Burden of History. Public Work. Manag. Policy 11, 233-238. doi:10.1177/1087724X06297319

Martin, T.., Brockhoff, C.A., Creed, J.T., Group, E.M.W., 1994. Method 200.7 Determination of Metals and Trace Elements in Water and Wastes. Environ. Monit. Syst. Lab. Off. Res. Dev. U. S. Environ. Prot. Agency 4.4, 1-58.

McKenzie-Mohr, D., Smith, W., 1999. Fostering Sustainable Behavior. New Society Publishers, Gabriola Island, BC, Canada.

Paneth, N., Vinten-Johansen, P., Brody, H., Rip, M., 1998. A rivalry of foulness: official and unofficial investigations of the London cholera epidemic of 1854. Am. J. Public Health $88,1545-53$.

Pontius, F.W., 2003. History of the Safe Drinking Water Act (SDWA). Pontius Water Consultants, Lakewood, Colorado.

Sarin, P., Snoeyink, V.L., Lytle, D.A., Kriven, W.M., 2004. Iron Corrosion Scales: Model for Scale Growth, Iron Release, and Colored Water Formation. J. Environ. Eng. 130, 364373.

Short, C., 2011. Water Portland's Precious Heritage, Second ed., Water Portland's Precious Heritage. Portland Water Bureau, Portland, Oregon.

U.S. Environmental Protection Agency, 1983. Methods for Chemical Analysis of Water and Wastes. U.S. E.P.A, Cincinnati, Ohio, USA.

U.S. Environmental Protection Agency, 1984a. EPA Your Drinking Water A Guide to Safe Drinking Water Regulations in Oregon.

U.S. Environmental Protection Agency, 1984b. EPA National Secondary Drinking Water Regulations. 
U.S. Environmental Protection Agency, 1999. 25 Years of the Safe Drinking Water Act: History and Trends EPA 816-R-99-007.

U.S. Environmental Protection Agency, 2000. The History of Drinking Water Treatment EPA816-F-00-006.

U.S. Environmental Protection Agency, 2001. Method 200.7 Trace Elements in Water, Solids, and Biosolids by Inductively Coupled Plasma-Atomic Emission Spectrometry EPA-821R-01-010. Washington, D.C.

U.S. Environmental Protection Agency, 2010. Code of Federal Regulations Title 40.

U.S. Environmental Protection Agency, 2013. Secondary Drinking Water Regulations: Guidance for Nuisance Chemicals [WWW Document]. URL http://water.epa.gov/drink/contaminants/secondarystandards.cfm (accessed 4.10.14).

U.S. Environmental Protection Agency Office of Water, 2004. Understanding the Safe Drinking Water Act EPA 816-F-04-030 [WWW Document]. URL http://water.epa.gov/lawsregs/guidance/sdwa/upload/2009_08_28_sdwa_fs_30ann_sdwa _web.pdf

United Nations, 2010. 64/292. The human right to water and sanitation, in: General Assembly. p. 3.

Villanueva, C.M., Kogevinas, M., Cordier, S., Templeton, M.R., Nuckols, J.R., Vermeulen, R., Nieuwenhuijsen, M.J., Levallois, P., 2014. Assessing Exposure and Health Consequences of Chemicals in Drinking Water: Current State of Knowledge and Research Needs. Environ. Health Perspect. 122, 213-221. doi:http://dx.doi.org/10.1289/ehp.1206229

Wilk, R., 2006. Bottled Water: The pure commodity in the age of branding. J. Consum. Cult. 6, 303-325. doi:10.1177/1469540506068681 

APPENDIX A

Standard Deviations of all samples.

\begin{tabular}{|c|c|c|c|c|c|c|c|c|c|c|c|}
\hline Sample Labels & $\begin{array}{l}\mathrm{Al} \\
236.705 \\
(\mathrm{ppb}) \\
\end{array}$ & $\begin{array}{l}\text { As } \\
193.696 \\
(p p b)\end{array}$ & $\begin{array}{l}\mathrm{Cd} \\
214.439 \\
(\mathrm{ppb})\end{array}$ & $\begin{array}{l}\mathrm{Cr} \\
267.716 \\
(\mathrm{ppb})\end{array}$ & $\begin{array}{l}\mathrm{Cu} \\
327.395 \\
(\mathrm{ppb})\end{array}$ & $\begin{array}{l}\mathrm{Fe} \\
238.204 \\
(\mathrm{ppb})\end{array}$ & $\begin{array}{l}\mathrm{Fe} \\
258.588 \\
(\mathrm{ppb})\end{array}$ & $\begin{array}{l}\text { Mn } \\
260.568 \\
(\mathrm{ppb})\end{array}$ & $\begin{array}{l}\mathrm{Ni} \\
231.604 \\
(\mathrm{ppb})\end{array}$ & $\begin{array}{l}\mathrm{Pb} \\
220.353 \\
(\mathrm{ppb})\end{array}$ & $\begin{array}{l}\mathrm{Zn} \\
206.200 \\
(\mathrm{ppb})\end{array}$ \\
\hline EastWmnsWC_l SD & 2.30 & 0.95 & 0.00 & 0.05 & 0.93 & 2.63 & 2.26 & 0.04 & 0.18 & 0.21 & 0.50 \\
\hline NorthWmns WC_2SD & 0.53 & 0.86 & 0.05 & 0.04 & 0.75 & 5.54 & 2.03 & 0.07 & 0.21 & 0.91 & 0.63 \\
\hline WestMensWC_3SD & 1.47 & 0.95 & 0.03 & 0.02 & 0.34 & 6.94 & 2.92 & 0.09 & 0.20 & 0.03 & 0.88 \\
\hline Anthropology_4 SD & 0.78 & 0.70 & 0.03 & 0.03 & 0.44 & 5.37 & 1.71 & 0.09 & 0.09 & 0.62 & 1.19 \\
\hline SHallWF_5SD & 1.13 & 0.37 & 0.03 & 0.01 & 0.40 & 5.55 & 3.11 & 0.02 & 0.14 & 0.44 & 0.61 \\
\hline Economics_6SD & 1.85 & 0.18 & 0.02 & 0.04 & 0.23 & 2.40 & 1.28 & 0.19 & 0.15 & 0.67 & 2.15 \\
\hline NHallWF_8SD & 1.65 & 0.31 & 0.02 & 0.03 & 0.23 & 4.43 & 3.02 & 0.02 & 0.04 & 0.69 & 0.77 \\
\hline Sociology_7 SD & 1.94 & 0.58 & 0.02 & 0.04 & 0.12 & 3.99 & 3.26 & 0.06 & 0.22 & 0.62 & 0.43 \\
\hline NorthWmnsWC_9SD & 0.24 & 0.43 & 0.01 & 2.10 & 2.10 & 2.55 & 1.81 & 0.04 & 0.13 & 0.85 & 0.90 \\
\hline Psychology1_10 SD & 0.13 & 0.33 & 0.03 & 0.01 & 0.29 & 4.37 & 2.77 & 0.04 & 0.44 & 0.58 & 1.20 \\
\hline EastWmnsWC_12 SD & 2.10 & 0.28 & 0.02 & 0.05 & 1.03 & 2.12 & 2.11 & 0.08 & 0.07 & 0.35 & 1.24 \\
\hline DeansOffice_13 SD & 1.96 & 0.31 & 0.04 & 0.04 & 0.53 & 3.75 & 2.68 & 0.04 & 0.20 & 0.08 & 0.43 \\
\hline HallWF_14 SD & 2.46 & 0.24 & 0.02 & 0.02 & 0.26 & 6.83 & 1.66 & 0.10 & 0.07 & 0.09 & 1.83 \\
\hline WHallWF_15 SD & 3.56 & 0.64 & 0.03 & 0.02 & 0.09 & 5.78 & 4.98 & 0.04 & 0.06 & 0.25 & 3.53 \\
\hline History_16SD & 0.77 & 0.28 & 0.03 & 0.03 & 0.24 & 0.54 & 0.71 & 0.17 & 0.25 & 0.32 & 3.36 \\
\hline Geography463_17SD & 2.09 & 0.59 & 0.02 & 0.03 & 0.13 & 5.28 & 1.30 & 0.18 & 0.19 & 0.35 & 4.26 \\
\hline Geography469_18SD & 1.37 & 1.14 & 0.04 & 0.02 & 0.19 & 2.35 & 1.92 & 0.13 & 0.42 & 0.65 & 3.84 \\
\hline 5thfloorWF_19SD & 0.41 & 0.47 & 0.01 & 0.03 & 0.04 & 2.98 & 1.40 & 0.26 & 0.27 & 0.35 & 3.24 \\
\hline Geology_20 SD & 1.57 & 0.55 & 0.04 & 0.04 & 0.25 & 5.03 & 0.72 & 0.11 & 0.09 & 0.47 & 1.87 \\
\hline$S B W F \_21 S D$ & 2.15 & 0.40 & 0.03 & 0.11 & 0.15 & 6.51 & 2.38 & 0.07 & 0.15 & 0.15 & 2.70 \\
\hline SBLabSink_22 SD & 0.47 & 0.74 & 0.01 & 0.08 & 0.11 & 1.42 & 1.28 & 0.19 & 0.28 & 0.14 & 0.30 \\
\hline WHallWF_15_4x SD & 0.37 & 0.17 & 0.02 & 0.03 & 0.02 & 0.49 & 0.81 & 0.01 & 0.14 & 0.58 & 1.05 \\
\hline Geography463_17_4x SD & 1.87 & 0.56 & 0.05 & 0.10 & 0.08 & 0.29 & 0.25 & 0.06 & 0.04 & 0.42 & 1.10 \\
\hline Geography469_18_4xSD & 1.50 & 0.67 & 0.03 & 0.02 & 0.06 & 0.16 & 0.11 & 0.01 & 0.25 & 0.74 & 0.76 \\
\hline
\end{tabular}


Intensities in counts of each of 22 sample locations, in addition to which standards were included based on final concentrations

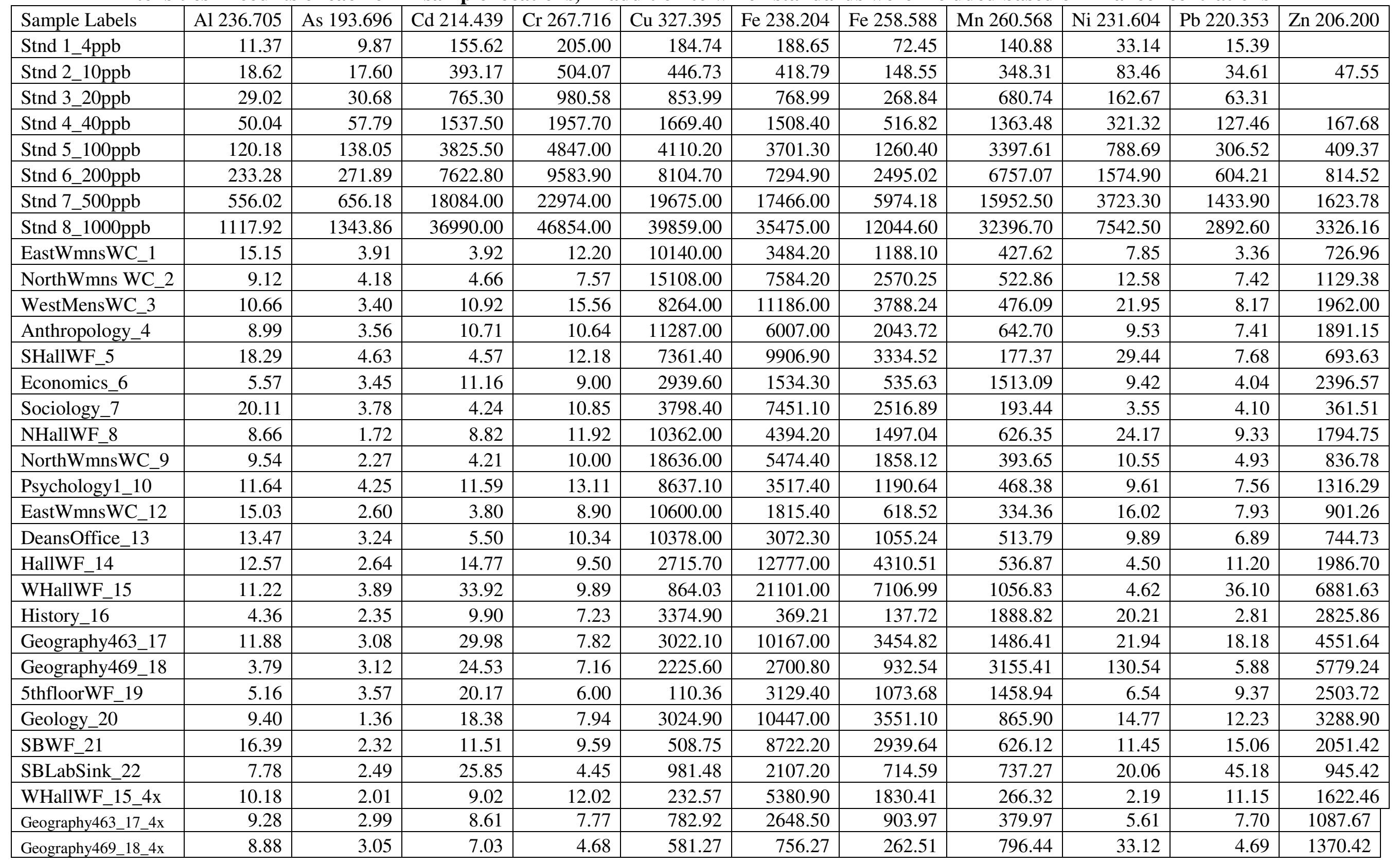


APPENDIX B

\section{Sample Preparation, Collection, and Preservation}

\section{Preparation}

Samplers are Nalgene 250 mL LDPE bottles (Part number B003OBYUSU).

1. Wash bottles, filter manifold, and glassware

a. Wash with Detergent [Sparkleen 1. Catalog No. 04-320-4]

b. Rinse with tap water-fill halfway, shake for 1-2 seconds, empty, repeat three times

c. Place directly in $4 \% \mathrm{HCl}$ acid bath for 48 hours (EPA-821-R-01-010 January 2001)

d. Rinse with deionized distilled water, shake excess water from bottles.

2. Cap tightly, dry outside of bottles, store.

3. Label metal pans 1-24 for filter drying.

(EPA-600/4-79-020, 1983, METALS-4)

\section{$\underline{\text { Collection }}$}

1. Label 22 A(1-24) bottles with sharpie on the lid, two sides, and bottom. 2 bottles will act as controls.

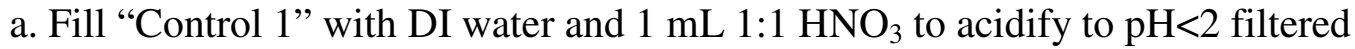
through the filter manifold. [Laboratory reagent blank] (Method 200.7 Revision 4.4 EMMC Version)

b. Fill "Control 2" with DI water and $1 \mathrm{~mL} \mathrm{1:1} \mathrm{HNO}_{3}$ to acidify to $\mathrm{pH}<2$ [Calibration blank] (Method 200.7 Revision 4.4 EMMC Version)

FOR EACH SAMPLE:

1. Put on gloves

2. Assign location to bottle number. bottle.

3. Open bottle, place bottle under tap, open tap, fill bottle to $250 \mathrm{~mL}$ mark. Close

4. Fill separate $500 \mathrm{~mL}$ bottle.

5. Record sample collection time, temperature, $\mathrm{pH}$, and conductivity for each sample.

$\underline{\text { Filtration and Acidification }}$

Option 1

1. Set up filter manifold, insert clean filter.

2. Pour liquid from bottle A [1-23] through vacuum filter. Turn on vacuum. Empty glassware back into bottle A. 
3. Remove filter from manifold. Place on metal dish. When 1-24 have been filtered, dry in drying oven.

4. Rinse manifold twice with DI water.

Repeat steps 2-4 for all samples.

5. [In fume hood] Add at least $0.15 \mathrm{ml} \mathrm{HNO3} \mathrm{(approximately} 15$ drops) to all samples to reduce the $\mathrm{pH}$ to less than 2 . Invert closed bottle 5 times.

6. Analyzation via Agilent 720 Axial Inductively Coupled Plasma Optical Emission Spectrometer 
APPENDIX C

EPA, WHO, EU regulations. Highlighted rows indicate the EPA regulates the contaminant only under secondary regulations

\begin{tabular}{|c|c|c|c|c|c|c|c|c|}
\hline$\sum^{\frac{\pi}{0}}$ & 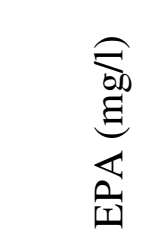 & 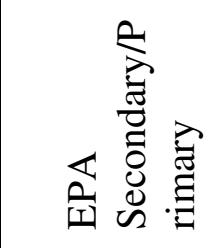 & 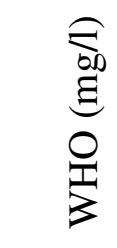 & 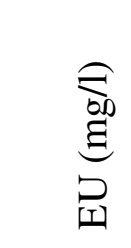 & $\begin{array}{l}\text { Potential Health Effects } \\
\text { from Long-Term } \\
\text { Exposure Above the } \\
\text { MCL (unless specified as } \\
\text { short -term) }\end{array}$ & Possible Sources & $\begin{array}{l}\text { Secondary } \\
\text { Concerns }\end{array}$ & $\begin{array}{l}\text { Noticeable Effects } \\
\text { above the } \\
\text { Secondary MCL }\end{array}$ \\
\hline $\mathrm{Al}$ & $\begin{array}{l}0.05- \\
0.2 \\
\end{array}$ & Secondary & 0.2 & 0.2 & & & \begin{tabular}{|l} 
Color, scale \\
and sediments
\end{tabular} & colored water \\
\hline As & 0.01 & Primary & 0.01 & 0.01 & $\begin{array}{l}\text { Skin damage or problems } \\
\text { with circulatory systems, } \\
\text { and may have increased } \\
\text { rick of getting cancer }\end{array}$ & $\begin{array}{l}\text { Erosion of natural deposits; runoff } \\
\text { from orchards, runoff from glass } \\
\text { and electronics production wastes }\end{array}$ & & \\
\hline $\mathrm{Cd}$ & 0.005 & Primary & 0.003 & 0.005 & kidney damage & $\begin{array}{l}\text { corrosion of galvanized pipes; } \\
\text { erosion of natural deposits; } \\
\text { discharge from metal refineries; } \\
\text { runoff from waste batteries and } \\
\text { paints }\end{array}$ & & \\
\hline $\mathrm{Cr}$ & 0.1 & Primary & 0.01 & 0.05 & allergic dermatitis & $\begin{array}{l}\text { discharge from steel and pulp } \\
\text { mills; erosion of natural deposits }\end{array}$ & & \\
\hline $\mathrm{Cu}$ & 1 & Secondary & 2 & 2 & $\begin{array}{l}\text { Short term exposure: } \\
\text { Gastrointestinal distress; } \\
\text { Long term exposure: liver } \\
\text { or kidney damage }\end{array}$ & $\begin{array}{l}\text { Corrosion of household plumbing } \\
\text { systems; erosion of natural } \\
\text { deposits }\end{array}$ & $\begin{array}{l}\text { Odor and taste, } \\
\text { Color, } \\
\text { corrosion and } \\
\text { staining }\end{array}$ & $\begin{array}{l}\text { metallic taste; blue- } \\
\text { green staining }\end{array}$ \\
\hline $\mathrm{Cu}$ & $\begin{array}{l}\text { TT, } \\
\text { Action } \\
\text { level } \\
1.3 \\
\end{array}$ & Primary & $\begin{array}{l}\text { see } \\
\text { abov } \\
\text { e }\end{array}$ & $\begin{array}{l}\text { see } \\
\text { above }\end{array}$ & & & & \\
\hline
\end{tabular}




\begin{tabular}{|c|c|c|c|c|c|c|c|c|}
\hline $\mathrm{Fe}$ & 0.3 & Secondary & none & 0.2 & & & $\begin{array}{l}\text { Odor and taste, } \\
\text { Color, } \\
\text { corrosion and } \\
\text { staining, scale } \\
\text { and sediments }\end{array}$ & $\begin{array}{l}\text { rusty color; } \\
\text { sediment; metallic } \\
\text { taste; reddish or } \\
\text { orange staining }\end{array}$ \\
\hline $\begin{array}{l}\mathrm{M} \\
\mathrm{n}\end{array}$ & 0.05 & Secondary & 0.5 & 0.05 & & & $\begin{array}{l}\text { Odor and taste, } \\
\text { Color, } \\
\text { corrosion and } \\
\text { staining }\end{array}$ & $\begin{array}{l}\text { black to brown } \\
\text { color; black } \\
\text { staining; bitter } \\
\text { metallic taste }\end{array}$ \\
\hline $\mathrm{Ni}$ & none & - & 0.02 & 0.02 & & & & \\
\hline $\mathrm{Pb}$ & $\begin{array}{r}\text { TT, } \\
\text { Action } \\
\text { level } \\
0.015 \\
\end{array}$ & Primary & 0.01 & 0.01 & $\begin{array}{l}\text { Infants and children: } \\
\text { Delays in physical or } \\
\text { mental development; } \\
\text { children could show } \\
\text { slight deficits in attention } \\
\text { span and learning } \\
\text { abilities. Adults: Kidney } \\
\text { problems; high blood } \\
\text { pressure }\end{array}$ & $\begin{array}{l}\text { Corrosion of household plumbing } \\
\text { systems; erosion of natural } \\
\text { deposits }\end{array}$ & & \\
\hline $\mathrm{Zn}$ & 5 & Secondary & 3 & $\begin{array}{r}\text { not } \\
\text { menti } \\
\text { oned }\end{array}$ & & & $\begin{array}{l}\text { Odor and taste, } \\
\text { corrosion and } \\
\text { staining }\end{array}$ & metallic taste \\
\hline
\end{tabular}


APPENDIX D

Sampling Location Maps

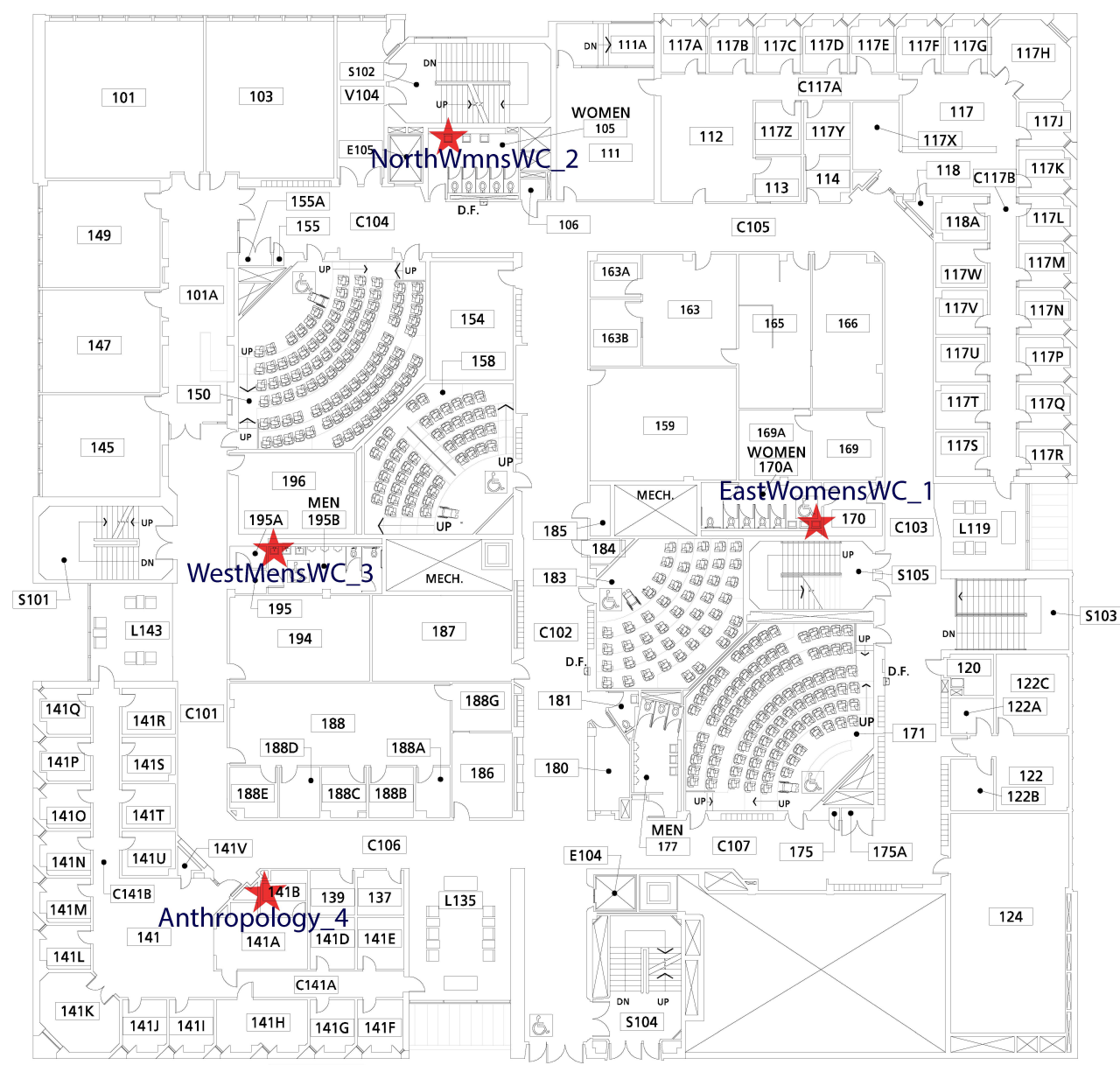




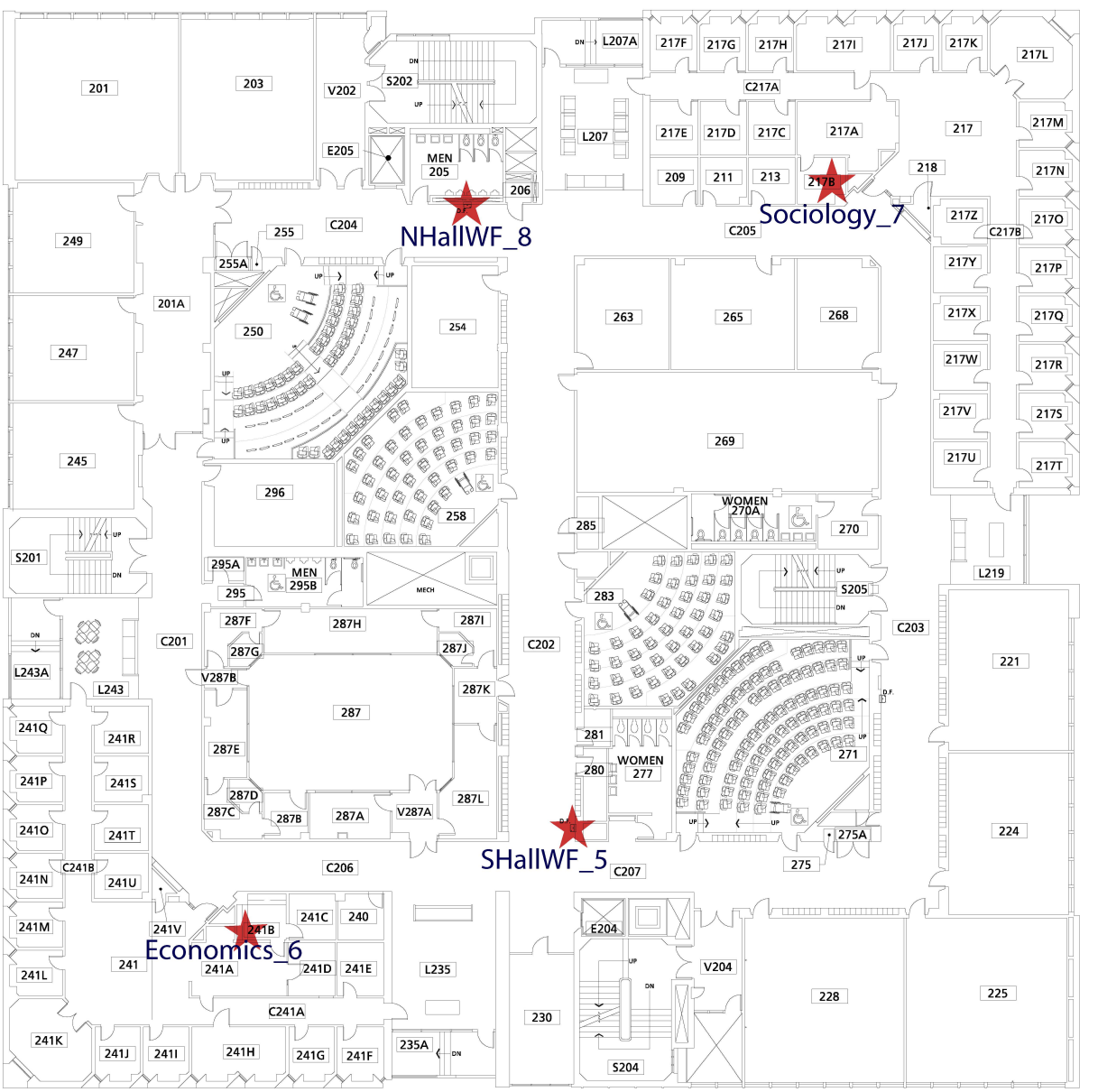

SECOND FLOOR PLAN
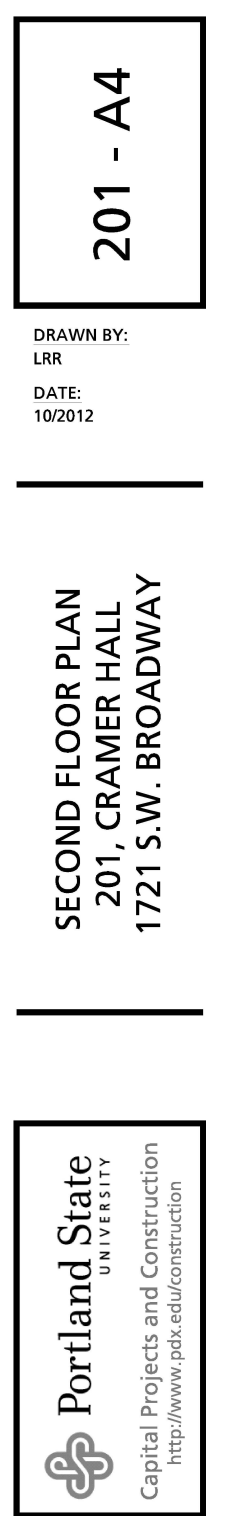
ENCLOSED PEDESTRRAN
SKY BRIOGE TO LINCOLN HALL

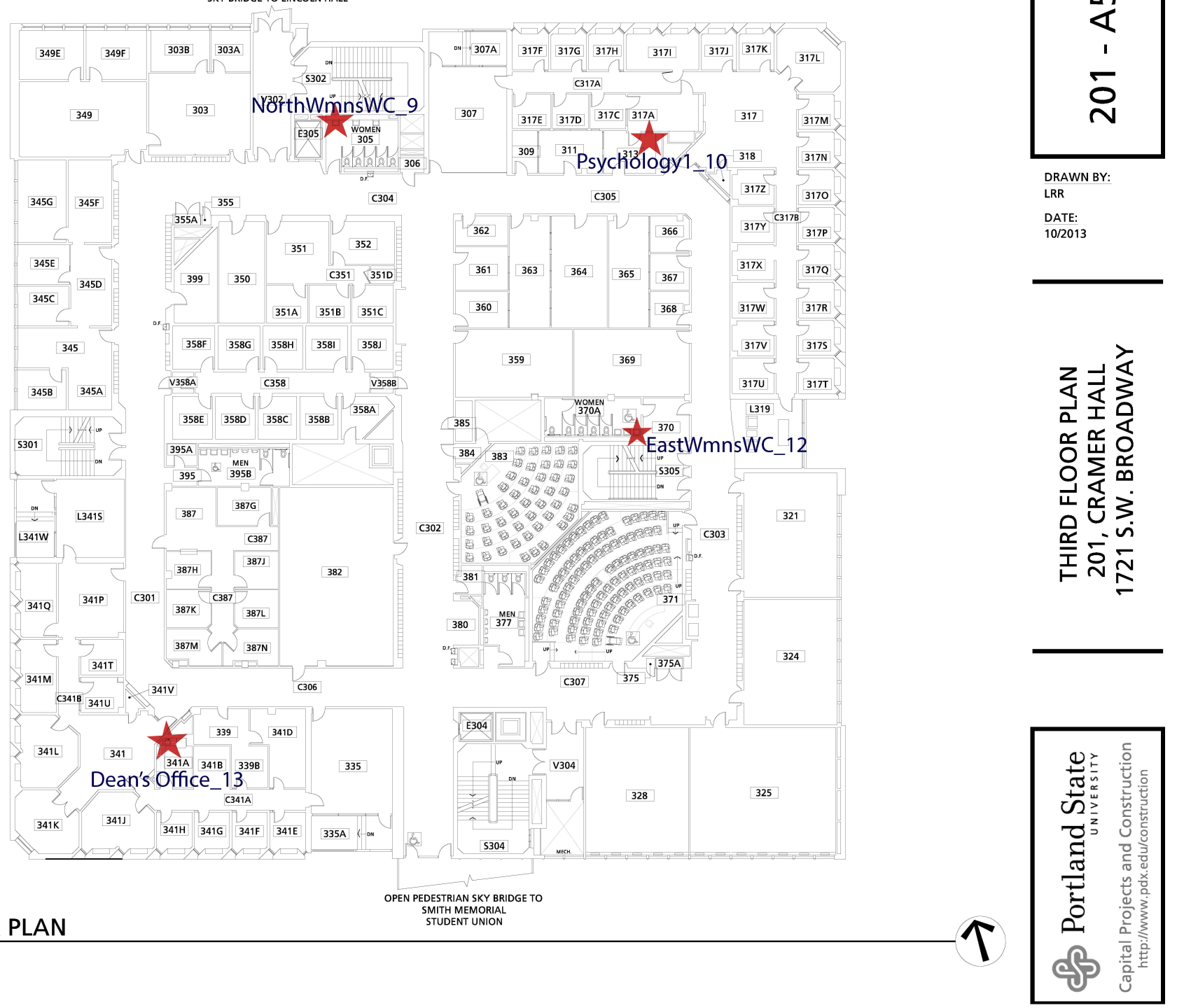




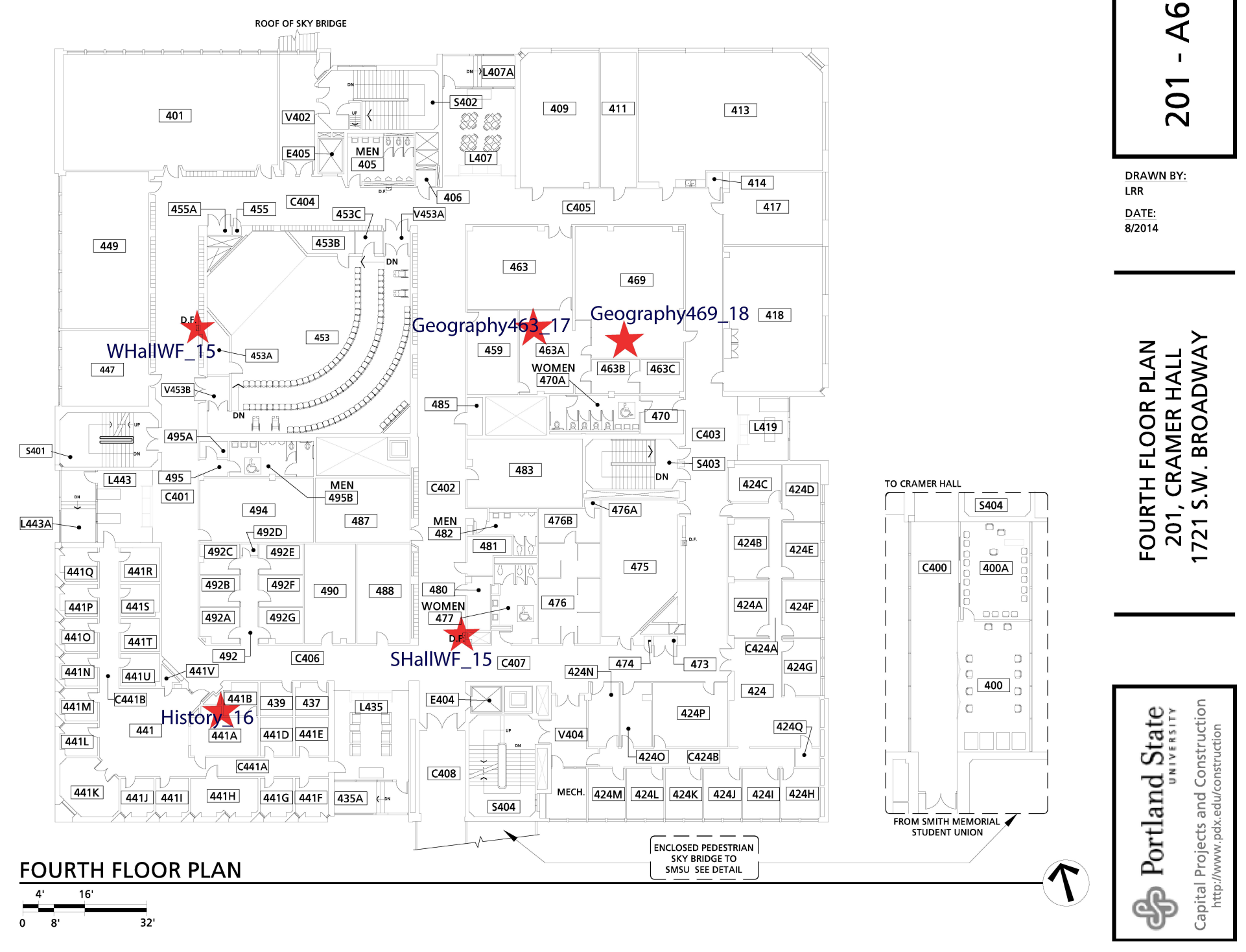




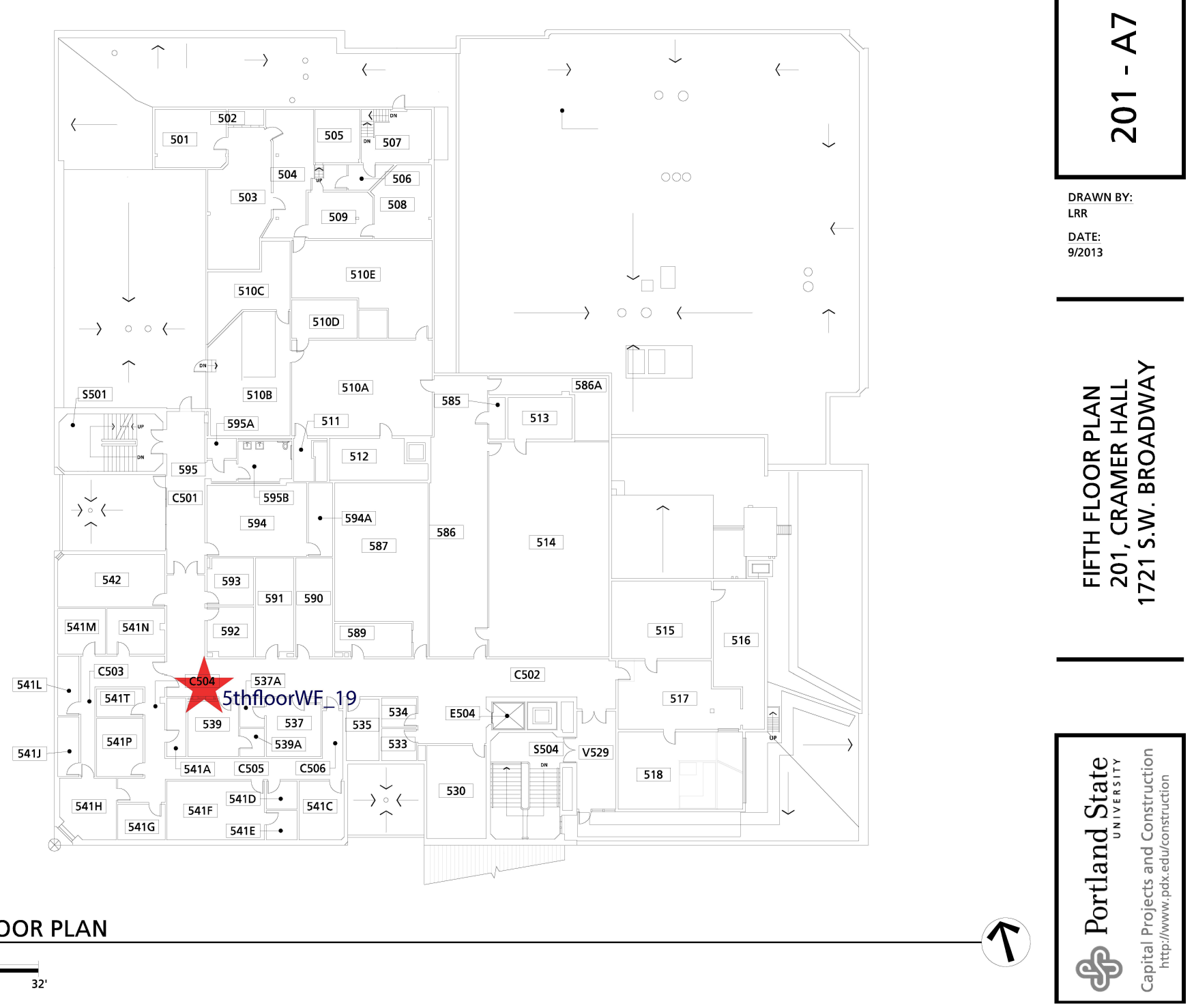




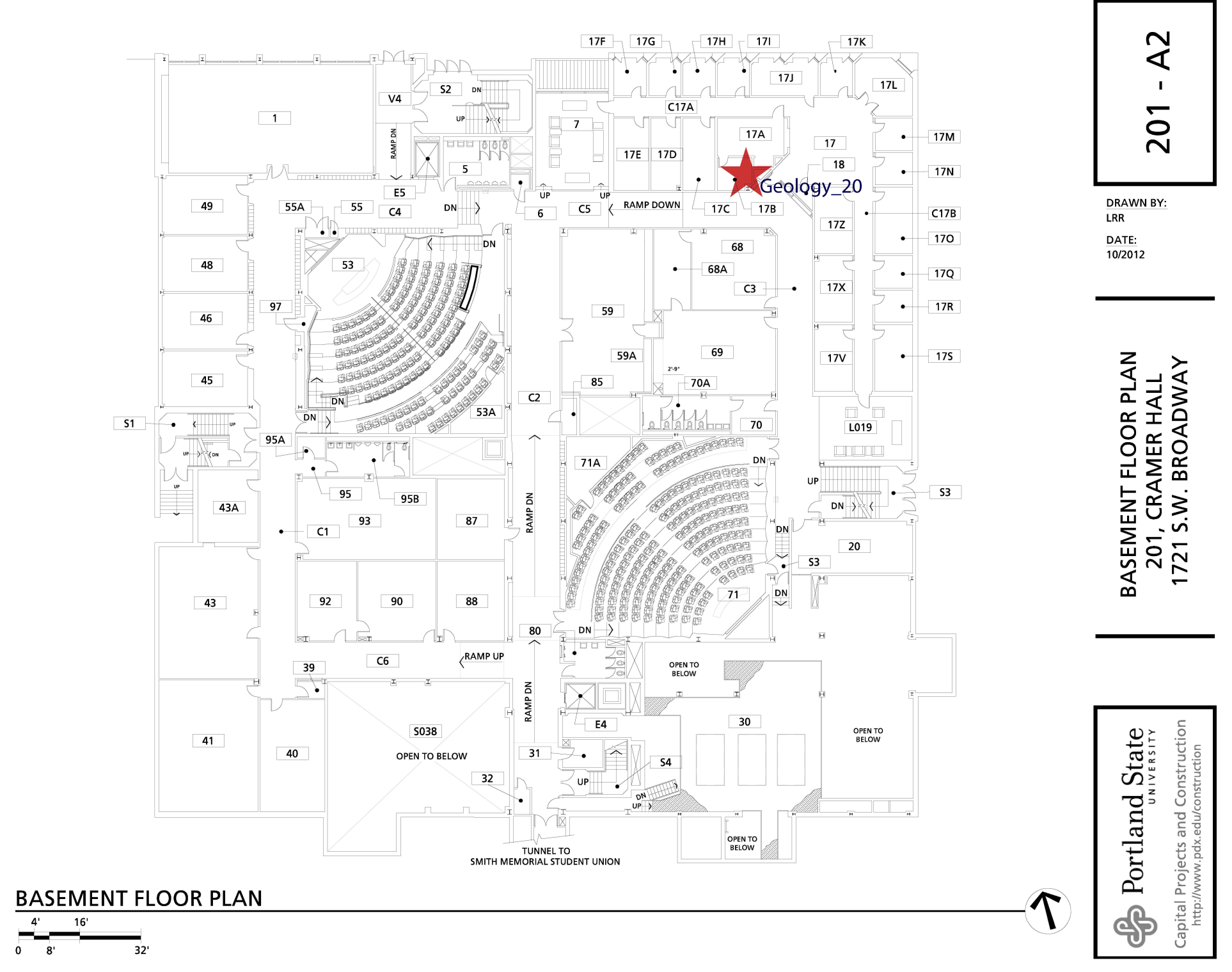




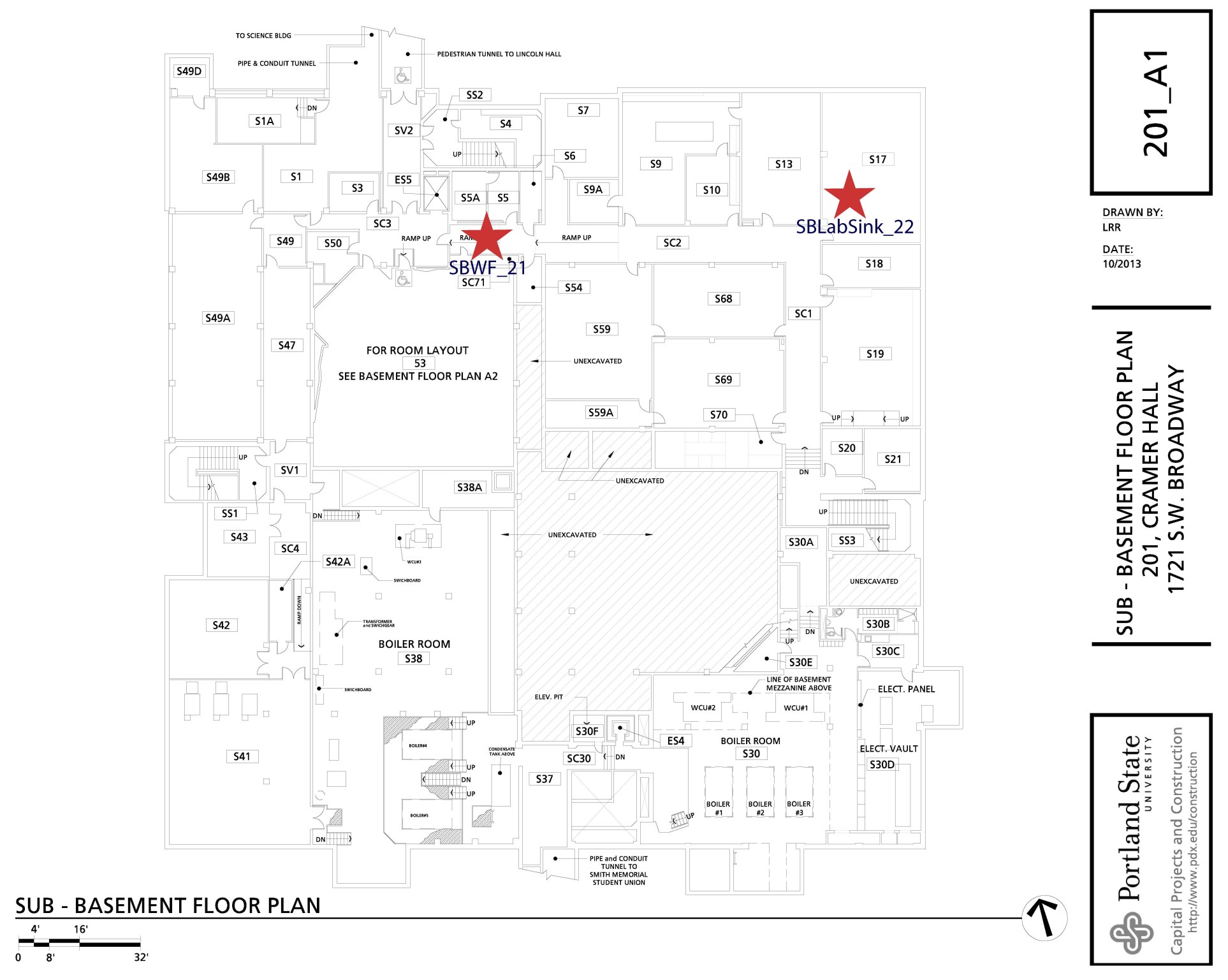



